\title{
航海術計算器の試作について
}

\section{For Trial Production of Nautical Calculators}

\section{堀 木 與 三 (䋁海訓練所) 大内 清 助 (玉屋商店)}

\section{〔1〕はしがを}

天測計算を主とする航海術計算を天测計算表, 航海表等を朋い數字計算を行 う事をく器 具を用いて機械的に計算をしようとする試みである。

數字計算を避ける方法として圖表を用いる方法と器具を用いる方法がある。天測計算の 中で最も面倒な高度計算は航海朋として五枌の精度を必要とし, 球面三角の原式を用いて 不等目盛となる雼に要領よく簡單に機械化する事は仲々困難である。

圖羕としては淺井氏航海圖表が航海用として完成實用に供せられて居るが器具としては 計算尺方式，天球方式のものが若干あるけれども航海用として精度，速度，價格，取扱等 に於て未だ必すしも實用の域に達して居ない樣に思はれるので計算尺方式を探用して機械 化を試みけものである。

最初は目盛をフイルム永のものに目盛る事を考えたのであるが，謴用化困難なる事が考 えられ，圆筒式のものに就て試作を行つたのであるが，更に圓盤式のものの方が精度，速 度，價格等に於てより合理的であると考光，後述の高度方位角盤，トラバース盤を中心と して一連の航海衍計算を行はんそずるものである。

\section{[2]高度方位角盤}

\section{用 途}

天測計算の高度方位角の計算を主だる目的とするものであるが，大圈航法, 經度算法等 の航海衍計算其他代弦，餘弦の精密なる一般の計算に應用する事が出來る。

\section{原 试}

原式としては機㮽化に都合の良い浇井氏航海圖表に用いられて居る次の $\sin , \cos$ 方式を 用いた。
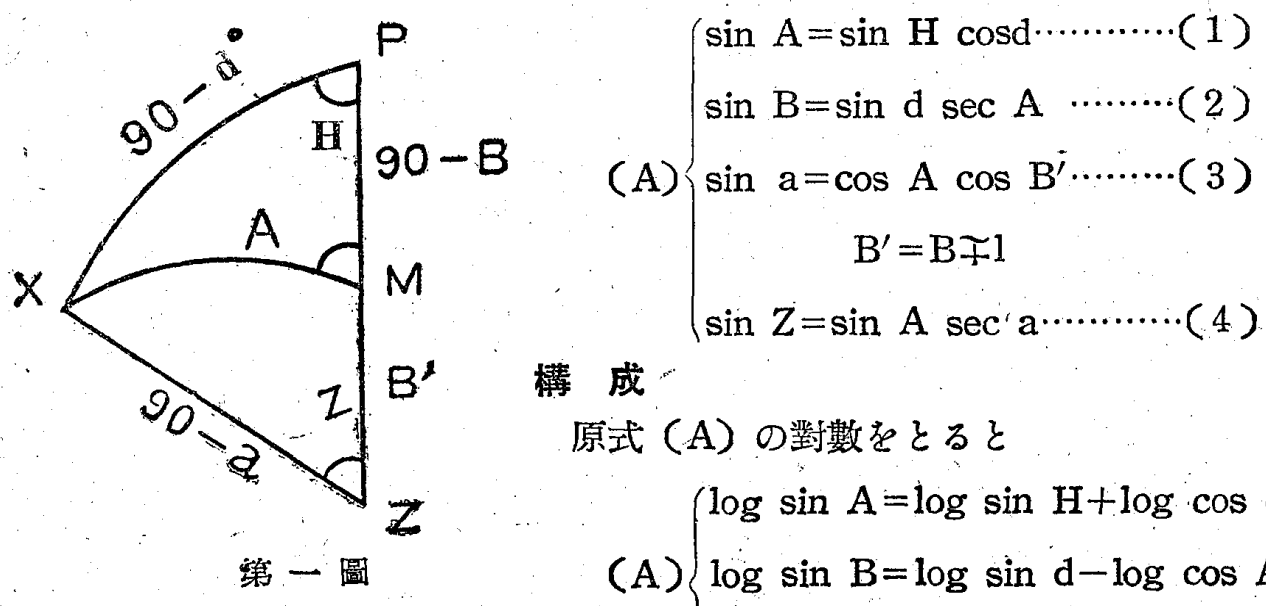

構 成

原式 (A) の對數をとると

(A) $\left\{\begin{array}{l}\log \sin A=\log \sin H+\log \cos d \cdots \cdots(1)^{\prime} \\ \log \sin B=\log \sin d-\log \cos A \cdots \cdots(2)^{\prime}\end{array}\right.$ 
$\mid \begin{aligned} & \log \sin a=\log \cos A+\log \cos B \\ & \log \sin Z=\log \sin A-\log \cos a\end{aligned}$

即ち $\sin$ 又は $\cos$ の對數に對する加減の計算である。

、從つて一枚の金屬盤に第二圖の如〈基準線を設け $\log \cos 0^{\circ}\left(\log \sin 90^{\circ}\right)$ より log $\cos$ $89^{\circ}-30^{\prime}\left(\log \sin 0^{\circ}-30^{\prime}\right)$ 迄同心圆上に外側上り內側に向つて中心角子以て目盛り遊標 二枚を上下に附す。

遊標は有機ガラス又はセルロイド等透明なものを用い，中心に指示線周綵に外側より各 同心圓に應じ指示數を表示す。

試作における圈盤の大ささは實用を考慮して直徑的 25 糎, 目盛は一般に角度 $1^{\prime}$ 迄表示 し，以下目算する事とし同心圓は 39卷，指示數の表示は第三圖の如く見易くした。

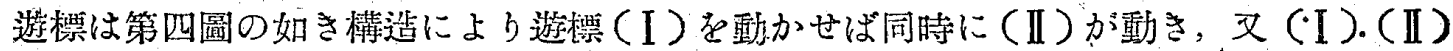
各單獨にも動き得る樣になつて居る。
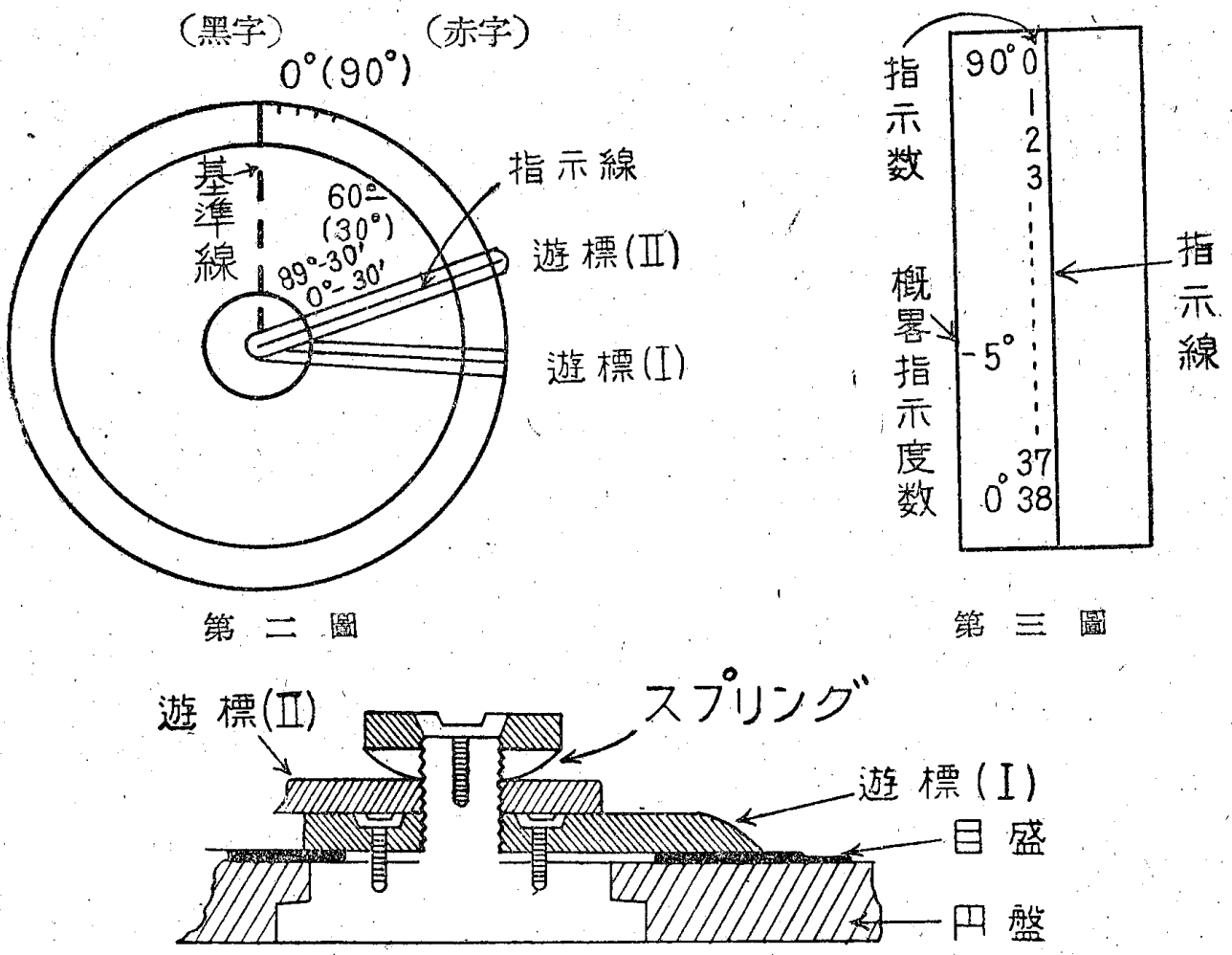

第 四 圖

\section{便 用 法}

1. A を求める法

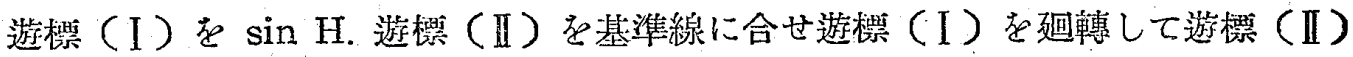
か $\cos \mathrm{d}$ になつた時の遊整 (I）の $\sin$ 目盛が求めるA である。

此の際 $\sin A$ に對する同心圓の指示數は $\sin \mathrm{H}$ と $\cos d$ の指示數の和である。

2. B长める法

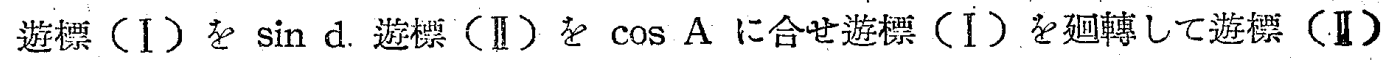

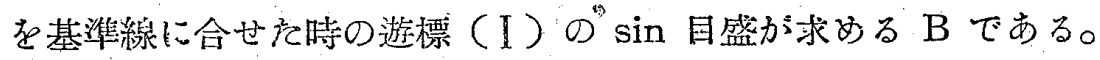

此の際 $\sin \mathrm{B}$ の指示數は $\sin \mathrm{d}$ と $\cos \mathrm{A}$ の指示數の差である。

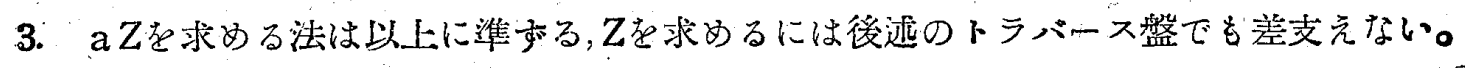


4. 特別の場合

イ $\mathrm{d}<0^{\circ}-30^{\prime}$ の時は $\mathrm{d} .1$ を入替えて $\mathrm{a}$ を求め $\mathrm{Z}$ は普通の方法で求める。

口 d. 1 共に $0^{\circ}-30^{\prime}$ 以下の時は $0^{\circ}-20^{\prime}$ の假定緯度を用いイの方法を用いる。

\section{實，用 化}

1. 精 度 (譏構的に簡單な)

一枚の盤が主哣であつて機械的な誤差の入る餘地が少く精度は五桁の一般船海表又は 航海圖表と略同-・であつて航泎用として賽用上充分であると洘える。更に精度を必要

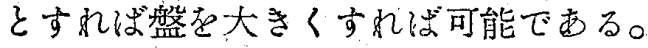

2. 速 度

未だ實驗が行はれて居ず習熟の度にもよるが極めて早く全計算を1分乃至 2 分程度 で行い得ると思う。

3. 價 格

原盤作製は相當面倒であるが大量生虚は簡單で圓筒式のものに比し $1 / 5$ 乃至 $5 / 10$ でよ いと思う。

4. 取 扱

使用，運搬が極めて簡單である。

\section{〔3〕トラバース盤}

\section{用 途}

1.中分緯度航法，距等圈航法，本面航法等推測航法に用いる。

2. 四桁の自然數に對する乘除計算

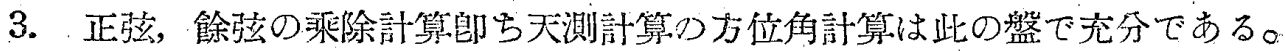

4. 一般直角三㞣形の計算

5. 正弦，餘弦に對する四桁以下の真數存求める換算 原式 中分緯度航法
D. lat $=$ Dist $\cos C_{0}$
(A)$$
\text { Dep }=\text { Dist } \sin \mathrm{C}_{0} \cdots \cdots \cdots(2)
$$$$
\text { D: } \text { Long }=\text { Dep sec M. lat } \cdots(3)
$$

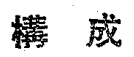

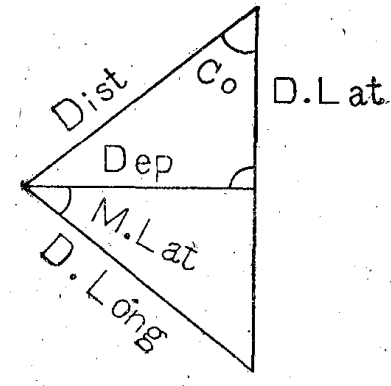

箩五圆

原式 (A) の對数をとるる

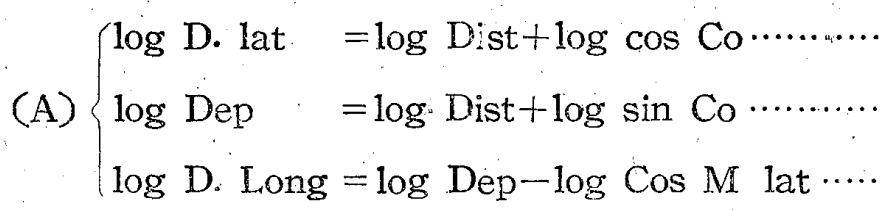

郎ち自然数亚て $\sin$ 又は $\cos$ の對數に對する加減の計算である。 從つて一杖の金屬盤に同心圆上外側上b第六圖の如く $100^{\prime}-1000^{\prime}$ 迄 (4雒) $1^{\prime}$ 間隔に

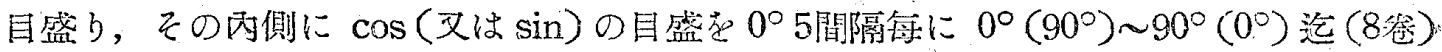
目盛つて遊橴二枚走附可。 遊䅺には各同心圆に應じ外側より第七圖の如く指示票を記大する。 其他は高度方位角盤の場合と同じである。 


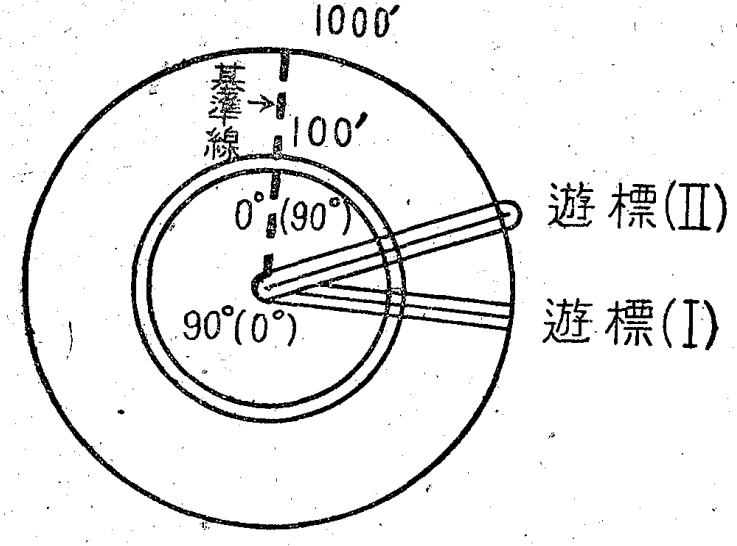

直経約 15 糎

第 六䔽
使 用 法

1. D. lat 尼求める法

Dist を外側， $\cos$ Co を內側目盛により

高度方位角盤に準じ求部。

2. Dep 在求める法

1によつて求め沈 D. lat に對する遊標

（I）を其睢とし遊䅺 (II) 存 $\sin$ Co に 合亏迄迴轉し遊標（I）によb求む。

3. D. Long 存求める法

2 によつて求めた Dep を其儘とし遊䅺 (II) 存 Cos m. lat 合せ基準線迄趈轉 して遊標（I）により求む。

位取 リ

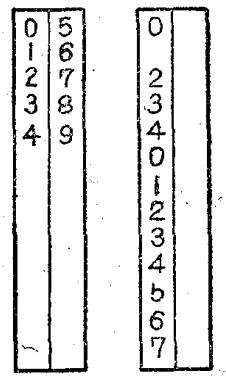

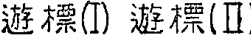

\begin{tabular}{|c|c|c|c|c|c|}
\hline 自然数 & $1000-100$ & $100-10$ & $10 \sim 0$ & $0=0.1$ & 備考 \\
\hline \multirow{3}{*}{ 指 } & 0 & 5 & 10. & 15 & \multirow{2}{*}{ 以. } \\
\hline & 1 & 6 & 11 & 16 & \\
\hline & 2 & 7 & 12 & 17 & \multirow[t]{2}{*}{ 同 } \\
\hline \multirow[t]{2}{*}{ 数 } & 3 & 8 & 13 & 18 & \\
\hline & 4 & 9 & 14 & 19 & \\
\hline
\end{tabular}

第 七 圖

實 用 化

トラバース表は極めて簡單で，器具化する必要はない椂であるが，次の點で必ずしむ無 駄ではないと考えた。

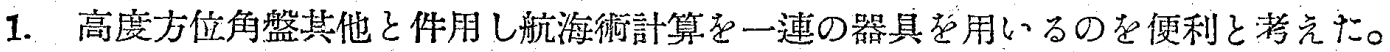

2. 速度に於てトラバース表は D. Long を求める方法が稍面倒であるが，本盤は D. lat, Dep., D, Long, 在連續に求める事が出來，“表の場合上り淆分便利であると考えだ。

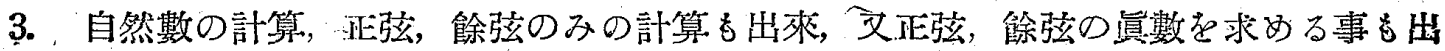
來，航海街計算以外の用途が相當豫期せられる。

4. 天測計算中方位任計算は此の盤を朋いた方が便利ではないかと洘えだ。

5. 製作も割合簡單で價格も割合低庵である。

6. 盤の裹面を利用し更に必要な計算又は換算目盛を表示し得る。

\section{[4]其他}

\section{時間角磨盤}

時間之角度の換算丈は計算の屚に高度方位角盤の外側等に第入圖の如く表示する。
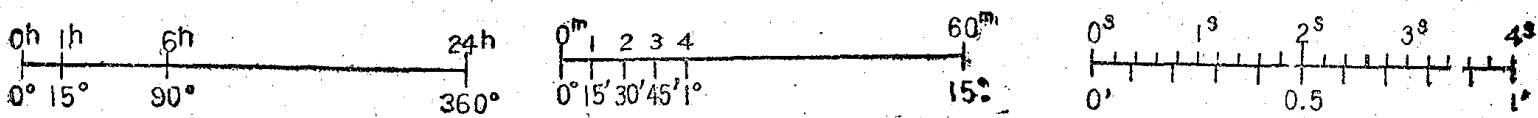

第入圆 


\section{位置 記 入盤}

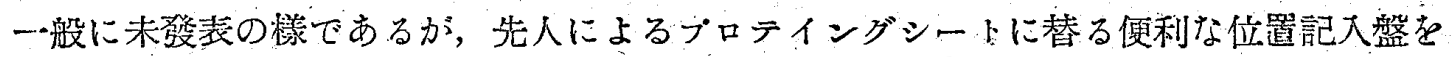

用いる。

\section{其他}

高度方位角盤邓はトラバース盤の㐮面に必要に應じ換算目盛等を表示する。

\section{〔5〕高度方位角筒}

前述の如く圓盤方式の前に圓筒式のもの老武作したのであるが，概略の記述に留め細部 に就ては省略する。

\section{蔧 造}

原式は圓盤の場合と同じである。

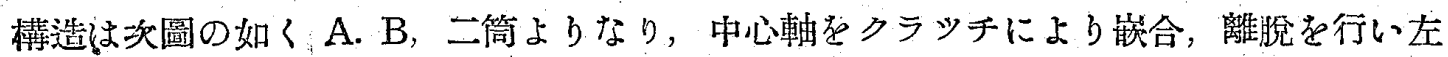
右にあるハンドルにより二筒官同時に又は單獨に迴轉し得る榜にしてある。（cos 目盛 以上には一般に使用されないか特别の考慮を拂う事により筫用上省略した)

目盛は直角方向に螺旋状に刻まれ，目盛の間に遊整の篇の溝がある。

遊標はハンドルの迴轉によつて中心軸に平行に移動する榚になつて居り，目盛の檄略位

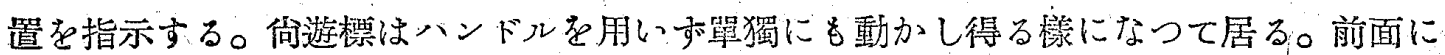
ガラス空を設け中心軸に本行に指示線を表示して，目盛を見得る稳になつて居る。少中

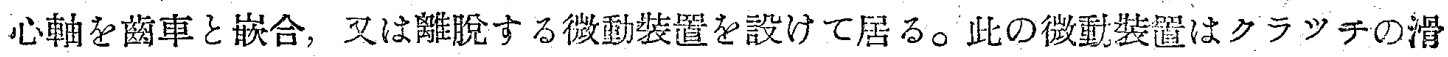
りによる誤差防止の役昌も果して居る。

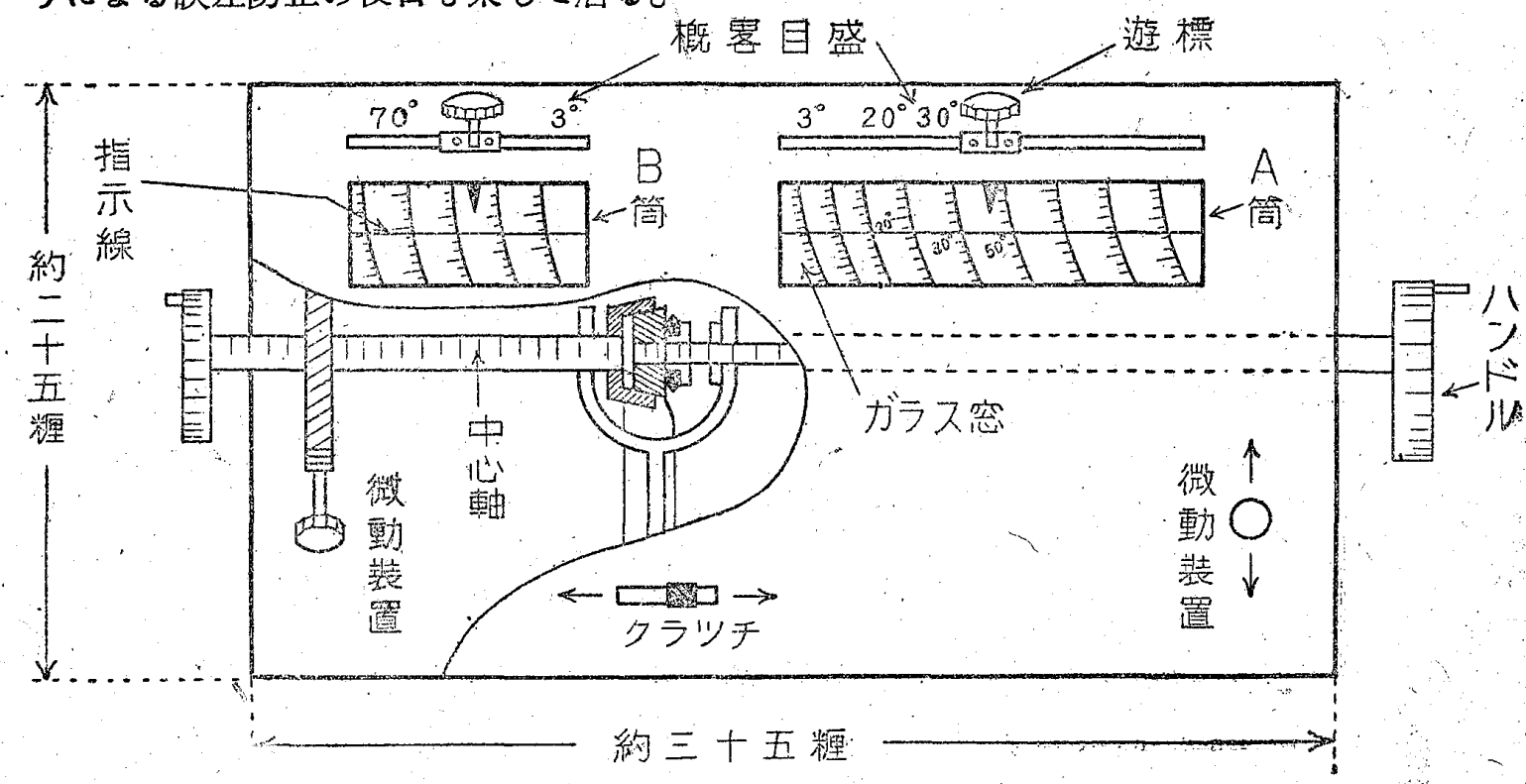

\section{便 的法}

$$
\text { 第九圖 }
$$

高度方位角盤に準ずる、細部に就ては省略する。

\section{あ \& か き}

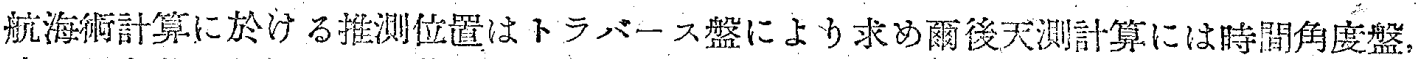

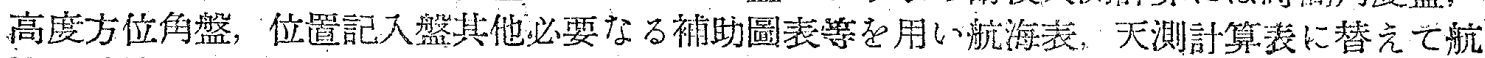

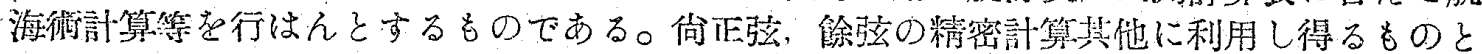

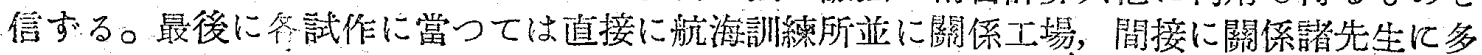
大の援助を产けたものであるが資用化して海運然發展の一助とな゙れば幸である。結果が思 はしくなくても關係方面の一示惨として御許し愿いたい。 